\title{
Characterization of Liquid Smoke From Coconut Shell Based Pyrolysis Process
}

\author{
Rahmi Eka Putri ${ }^{1 *}$, Anwar Kasim ${ }^{2}$, Emriadi $^{3}$ and Alfi Asben ${ }^{2}$ \\ \{rahmistppmedan@gmail.com*
}

\author{
${ }^{1}$ Postgraduate Doctoral Program, Andalas University, Padang, Indonesia \\ ${ }^{1}$ Sekolah Tinggi Penyuluhan Pertanian Medan, Ministry of Agriculture, Medan, 20002, Indonesia \\ ${ }^{2}$ Faculty of Agricultural Technology, Andalas University, Padang, Indonesia \\ ${ }^{3}$ Faculty of Mathematics and Natural Sciences, Andalas University, Padang, Indonesia
}

\begin{abstract}
Liquid smoke produced from coconut shell by pyrolysis process. The pyrolizermade of a $12 \mathrm{~kg}$ gas tube that is rust resistant and can be dismantled.The aimed of this research was to explore the liquid smoke characterization of coconut shell by pyrolysis process. The result showed that yield of pyrolysis from coconut shell is $46.02 \%$. Chemical components of liquid smoke which is produced via pyrolysis of coconut shell has been analyzedusing gas chromatography mass spectroscopy (GC-MS).The results identified as many as 48 chemical compounds that exist in the liquid smoke coconut shell.Overall, phenol, ammonium acetate and furfural were the highest concentration of chemical obtained in this research.
\end{abstract}

Keywords: Coconut Shell, Pyrolysis, Liquid Smoke, Chemical Compound.

\section{Introduction}

Coconut is a tropical plant that is often called "Tree of Life" or "Tree of Heaven" because this plant has many uses and most important economic value from fruit to roots. According to the data from (Dirjenbun, 2016)coconut production in Indonesia reached 2.9 million tons.In line with the increase of coconut production from year to year, on the other handalso increase the volume of waste generated.

Coconut shell is one of the waste from coconut. The smallest percentage of coconut shells is $12 \%$ of the weight of whole coconut. Coconut shells have a hard texture because of lignin, cellulose and hemicellulose as their component. Coconut shells have been widely used for the manufacture of charcoal and activated charcoal. One of the alternative technologies that can be used to treat coconut shell waste is pyrolysis method(Darmadji, 2002; Devison, 2015).

The charcoal industry in Indonesia currently only prioritizes charcoal as its product while the remaining $70-80 \%$ is in the form of vapor or gas waste dumped freely into the air as pollutants. Efforts to increase the added value of products from smoke to environmentally friendly have been done with the research utilization of changing smoke in liquid form called wood vinegar or liquid smoke(Nurhayati, T., 2005).

Pyrolysis is one of the few biofuel technologies that can handle a range of biomass feedstocks (agri-residues, forest residues, energy crops, municipal solid wastes). It is an attractive option for expanding the possibilities of using less desirable biomass. Pyrolysisis a combustion processwithout oxygen which one in the process will convert the contentoflignocellulose in biomass into liquid, charcoal and gas products (Roy and Dias, 
2017). The proportion of these three products depend on pyrolysis method, biomass characterization and reaction parameters (Hermanto and Farizy, 2014). The flexibility of pyrolysis to generate solid, liquid and gaseous as a combination of products was interesting to study about variations of operating parameters (Czajczyńska et al., 2017). Typically,apyrolizer consists of a reactor, cyclone and condenser. Biomass is fed into the reactor and converted into different products via variousthermochemical reactions.

To produce a qualified liquid smoke and optimal liquid smoke yield was required a pyrolizer that can increase the quantity and quality of liquid smoke.

The pyrolizer designed by the previous researcher is in the form of a cylindrical column derived from a stainless steel plate, an oil drum that is generally easy to rusty. The previous design was madepyrolizer from stainless steel plate, tool capacity for coconut shell, coconut husk and rice husk each 1.25; 0.45; and $0.32 \mathrm{~kg} /$ hour (Syafri, E danNovita, S. A., 2011). Developed a liquid smoke-generating device of rice husk, 2-hour pyrolysis and produced a volume of $1,3 \%$ of liquid smoke(Putri, Mislaini and Ningsih, 2015).

To increase the economic value of the coconut shell the researcher was interesting to process it into liquid smoke using a pyrolizer from a $12 \mathrm{~kg}$ gas tube and studying the chemical content of liquid smoke.

\section{Materials And Methods}

\subsection{Raw Material}

Coconut shells were obtained from Padang, West Sumatra, Indonesia. They were cleaned from the remaining coconut husk and the flesh of fruit, cut into small size $\pm 2 \times 3 \mathrm{~cm}$ andthen sun-dried for a week.

\subsection{Research Methods}

The research method was done by literature study on the design of pyrolizerfrom previous researchers. The combustion process takes 5.5-6.5 hours and obtained liquid smoke yield of coconut shell $21.74 \%$ from pyrolysis design of $3 \mathrm{~mm}$ thick stainless steel plate with $50 \mathrm{~cm}$ in diameter and $80 \mathrm{~cm}$ in height(Syafri, E dan Novita, S. A., 2011). The performed a 60 $\mathrm{kg}$ pyrolysis design, $60 \mathrm{~cm}$ in diameter and $90 \mathrm{~cm}$ in height obtainedyield of liquid smoke for coconut shell was 43,93\%(Devison, 2015). Based on the research results, experiments were conducted to design a liquid smoke device that is portable, and stainless. The manufacture of aliquid smoke makers consists of pyrolysis tube, smoke distribution pipes, cooling pipes, liquid water cooling drums, and liquid smoke containers.

Stagesin the manufacture of liquid smoke from various types of agricultural waste materials usingexperimentalmethods.Each treatment was performed with two replicates on each feedstock.Each raw materialfilled as much as $2 / 3$ of the tube height and tightly sealed and pyrolysis process is done until no more condensation liquid drips.

\subsection{Laboratory Analysis}

Chemical analysiswas done by using Spectrofotometry and Gas Chromatography method using GC-MS brand Shimadzu QP 2010 plus with operational condition of injection temperature $210^{\circ} \mathrm{C}$, column temperature $100^{\circ} \mathrm{C}$, temperature rise $10^{\circ} \mathrm{C} / \mathrm{min}$, helium carrier gas, pressure $111 \mathrm{Kpa}, \mathrm{Rtx} \_5 \mathrm{MS}$ column type $(30 \mathrm{~m} \times 0.25 \mathrm{~mm})$. 


\section{Results And Discussion}

\subsection{Design of Pyrolizer}

Pyrolizer is a device to produced liquid smoke, a series of liquid smoke makers consisting of pyrolysis tubes, smoke distribution pipes, condensers, and liquid smoke containers. Pyrolizerwas modified to get a portable and stainless results. It also obtained the maximum yield of liquid smoke.

Capacity productionof pyrolizer is for $6 \mathrm{~kg}$ coconut shell. The specification of pyrolizer are: pyrolysis tube made from $12 \mathrm{~kg}$ of LPG gas tube which is cut at the top and added chimney on top. Size of tube was diameter $28 \mathrm{~cm}$, tube height $38 \mathrm{~cm}$ and volume 23.3 liter. The condenser is a spiral pipe that was inserted into a drum containing water.The pipe used is made of $2 \mathrm{~mm}$ thick stainless steel, 0.75 inch diameter, $35 \mathrm{~cm}$ spiral coil diameter and 9 spiral circumference. The smoke distribution pipes are made of stainless steel pipes $2 \mathrm{~mm}$ thick, 0.75 inches in diameter and $1.75 \mathrm{~m}$ long.

\subsection{Pyrolysis Results}

The gas obtained is a gas thatcannot be condensed by the condenser. It was cannot be accommodated in a liquid container. Some of these gases are trapped inthe container while others go through the pipes into the atmosphere. The volatile components include $\mathrm{CO}_{2}, \mathrm{CO}$, $\mathrm{CH}_{4}$ andother low-level hydrocarbons.

Table 1: Yield of Coconut Shell Pyrolysis for 5 Hours

\begin{tabular}{|c|c|c|c|c|c|c|}
\hline \multirow[t]{2}{*}{ Biomass } & \multirow{2}{*}{$\begin{array}{l}\text { Weight } \\
\text { Material } \\
(\mathrm{kg})\end{array}$} & \multirow{2}{*}{$\begin{array}{l}\text { Temp } \\
\operatorname{Max}\left({ }^{\circ} \mathrm{C}\right)\end{array}$} & \multicolumn{4}{|c|}{ Pyrolysis Products } \\
\hline & & & $\begin{array}{l}\text { Liquid Smoke } \\
(\%)\end{array}$ & $\begin{array}{l}\text { Ter } \\
(\%)\end{array}$ & $\begin{array}{l}\text { Charcoal } \\
(\%)\end{array}$ & $\begin{array}{l}\text { Missing } \\
\text { Materials (\%) }\end{array}$ \\
\hline Coconut Shell & 6 & 220 & $46,02 \pm 1,37$ & 8,34 & 36,71 & 8,93 \\
\hline
\end{tabular}

The yield of coconut shell pyrolysis can be seen in Table 1.Liquid smoke product from this study was dark brown. Liquid smoke started out in the process of pyrolysis at minute 24 with a temperature of $95^{\circ} \mathrm{C}$, while in the $7^{\text {th }}$ minute that came out only smoke with a temperature of $65^{\circ} \mathrm{C}$.

Once decanted for 1 week formed two layers in the liquid smoke liquid. The brownish top layer is a liquid smoke and a thick black undercoat is a tar. Based on Table 1, the average yield of liquid smoke produced in the process of coconut shell pyrolysis from modified gas cylinders at $220^{\circ} \mathrm{C}$ for 5 hours is $46.02 \%$. Therefore the yield of liquid smoke produced by pyrolysis from the experiment has reached the maximum yield. This result is more than previous pyrolizer design made by (Devison, 2015) with a yield of $43.39 \%$.

\subsection{Characterization of Compounds in Liquid Smoke Using GC-MS}

GC-MS analysisperformed to determine the chemical content contained in coconut shell liquid smoke. The depiction of a curved chromatogram pattern as a function of time for gas chromatography and spectrogramming is in the form of line spectra for mass spectrometry showing the mass spectral pattern of fragmentation results from the sample molecules.

Figure 1 showed a chromatogram of coconut shell liquid smoke. The peak appeared at the retention time of 1.385 - 19.460 minutes and identified 48 compounds. The compounds are suspected to have the names and structures as listed in Table 2. The most common chemical content of liquid smoke is phenol followed by ammoniumacetate and furfural. The same result 
for the phenolic content of the palm shell is $21.02 \%$ (Haji, 2013). Phenolic compounds of liquid smoke from Lamtoro and Corn cob were: 481,2 ppm and 335 ppm (Swastawati, 2007). Identification of GC-MS of cacao shell could provide compounds that mostly derived from acetone $13.01 \%$, acetate acid $73,86 \%$, 2buthanone $6,60 \%$, methyl ester $2,46 \%$, and propanoic acid 4,07\% (Hermanto and Farizy, 2014).

Phenol in smoke is one of thermal degraded results of lignin in wood. Pyrolysis of hemicellulose will produce furfural, furan and its derivatives together with long chains of carboxylic acids while hemicellulose pyrolysis together with cellulose to form acetic acid and homologous. The second pyrolysis reaction of cellulose forms acetic and homologous acids together with water and sometimes together with lignin to form furan and phenol (Darmadji, 2002).

\section{Conclusions}

From this study can be concluded that the design of pyrolizer from gas tubes of $12 \mathrm{~kg}$ can produced maximum yield for liquid smoke. Pyrolizer was modified to get a portable and stainless results. The yield of liquid smoke from coconut shell was $46,02 \%$.

GC-MS indicated that chemical componets of coconut shell liquid smoke consists of 48 compounds. Chemical components with the highest concentration are phenol, ammonium acetate and furfural

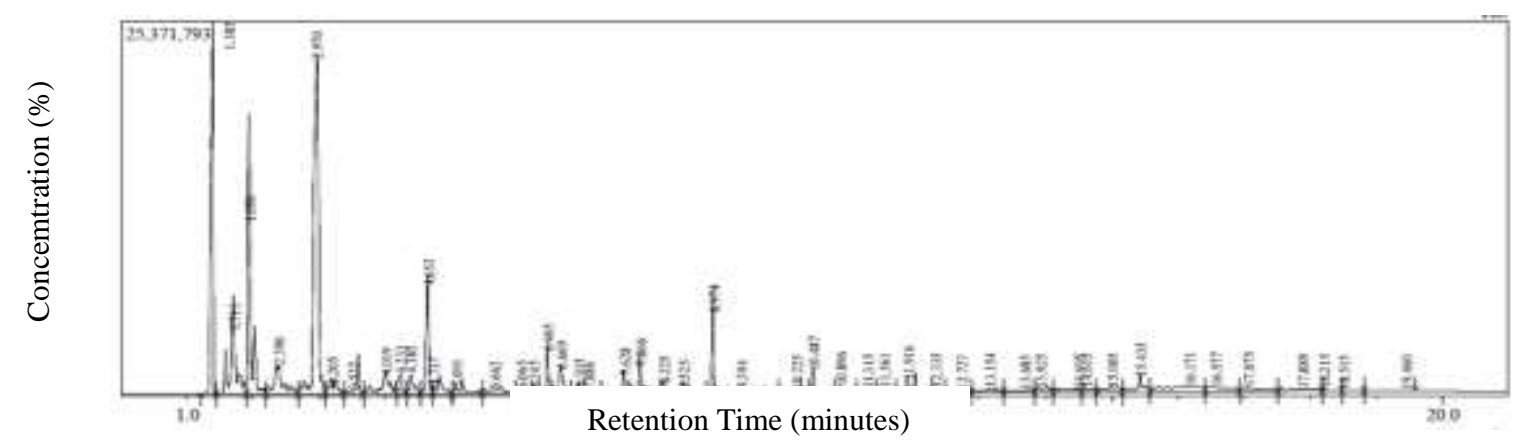

Fig. 1. Chromatogram of Liquid Smoke from Coconut Shell

Table 2. GC-MS Analysis of Liquid Smoke from Coconut Shell

\begin{tabular}{llll}
\hline Peak & \multicolumn{2}{c}{ Retentio } & Chemical Content \\
Number & $\begin{array}{l}\text { Time } \\
\text { (minute) }\end{array}$ & & $\begin{array}{l}\text { Concentratio } \\
\mathrm{n} \\
(\%)\end{array}$ \\
\hline 1 & 1.385 & Ammonium acetate & 11.19 \\
2 & 1.713 & 1-Hydroxy-2-butanone & 5.94 \\
3 & 1.950 & Furfural & 11.05 \\
4 & 2.390 & V Butyrolactone & 3.56 \\
5 & 2.970 & Phenol & 21.80 \\
6 & 3.205 & 2H-Pyran-2-one, 5,6-dihydro-3,5,5-trimethyl- & 1.43 \\
7 & 3.527 & 1-Felinine & 1.60 \\
8 & 4.019 & Phenol, 2-methyl- & 2.60 \\
\hline
\end{tabular}




\begin{tabular}{|c|c|c|c|}
\hline $\begin{array}{l}\text { Peak } \\
\text { Number }\end{array}$ & \begin{tabular}{l}
\multicolumn{2}{l}{ Retentio } \\
n Time \\
(minute)
\end{tabular} & Chemical Content & $\begin{array}{l}\text { Concentratio } \\
\mathrm{n} \\
(\%)\end{array}$ \\
\hline 9 & 4.233 & 2-Furanmethanol, tetrahydro & 1.05 \\
\hline 10 & 4.385 & Phenol, 3-methyl- & 1.17 \\
\hline 11 & 4.652 & Phenol, 2-methoxy- & 4.10 \\
\hline 12 & 4.737 & 2-Cyclopenten-1-one, 3-ethyl-2-hydroxy- & 1.36 \\
\hline 13 & 5.091 & Maltol & 1.06 \\
\hline 14 & 5.662 & Ethanone, 1-(6-methyl-7-oxabicyclo[4.1.0]hept-1-yl)- & 1.09 \\
\hline 15 & 6.065 & Phenol, 4-ethyl- & 0.55 \\
\hline 16 & 6.245 & Phenol, 3,4-dimethyl- & 0.24 \\
\hline 17 & 6.465 & Phenol, 2-methoxy-4-methyl- & 1.62 \\
\hline 18 & 6.669 & 1,2-Benzenediol & 1.97 \\
\hline 19 & 6.935 & ,4:3,6-Dianhydro-.alpha.-d-glucopyranose & 0.49 \\
\hline 20 & 7.086 & 2-Furancarboxaldehyde, 5-(hydroxymethyl)- & 0.45 \\
\hline 21 & 7.628 & 1,2-Benzenediol, 3-methoxy & 1.24 \\
\hline 22 & 7.866 & Phenol, 4-ethyl-2-methoxy- & 2.14 \\
\hline 23 & 8.225 & 1,2-Benzenediol, 4-methyl- & 0.96 \\
\hline 24 & 8.525 & Menthyl salicylate & 0.72 \\
\hline 25 & 8.974 & Phenol, 2,6-dimethoxy- & 4.59 \\
\hline 26 & 9.394 & Dodecane, 1-bromo- & 0.69 \\
\hline 27 & 10.225 & Benzoic acid, 4-methoxy- & 0.14 \\
\hline 28 & 10.487 & Trimethoxybenzene & 1.02 \\
\hline 29 & 10.896 & Methylparaben & 0.43 \\
\hline 30 & 11.315 & Ethanone, 1-(4-hydroxy-3-methoxyphenyl)- & 0.25 \\
\hline 31 & 11.561 & D-Allose & 0.26 \\
\hline 32 & 11.916 & Benzene, 1,2,3-trimethoxy-5-methyl- & 1.61 \\
\hline 33 & 12.335 & beta.-d-Ribopyranoside, methyl, 3 -acetate & 0.31 \\
\hline 34 & 12.727 & 2H-1-Benzopyran-2-one, 8-hydroxy- & 0.43 \\
\hline 35 & 13.154 & Phenol, 2,6-dimethoxy-4-(2-propenyl)- & 0.74 \\
\hline 36 & 13.685 & Benzenemethanol, 2-methyl-.alpha--phenyl- & 0.61 \\
\hline 37 & 13.925 & 2(3H)-Naphthalenone, $4,4 \mathrm{a}, 5,6,7,8$-hexahydro-4a- & 0.62 \\
\hline 38 & 14.495 & methyl- & 0.75 \\
\hline 39 & 14.615 & Dihydroartemisinin, 10-O-(t-butyloxy)- & 0.38 \\
\hline 40 & 15.005 & Phenol, 2,6-dimethoxy-4-(2-propenyl)- & 0.78 \\
\hline 41 & 15.435 & Ethanone, 1-(4-hydroxy-3,5-dimethoxyphenyl)- & 1.31 \\
\hline 42 & 16.171 & Desaspidinol & 2.23 \\
\hline 43 & 16.577 & Ethanone, 1-(4-hydroxy-3,5-dimethoxyphenyl)- & 1.20 \\
\hline 44 & 17.075 & Heptasiloxane, & 0.90 \\
\hline 45 & 17.889 & Hexadecanoic acid, methyl ester & 0.69 \\
\hline 46 & 18.215 & n-Hexadecanoic acid & 0.21 \\
\hline 47 & 18.515 & Tetradecanoic acid & 0.14 \\
\hline 48 & 19.460 & $\begin{array}{l}\text { 3,5-Dimethoxy-4-hydroxycinnamaldehyde } \\
\text { Octasiloxane }\end{array}$ & 0.16 \\
\hline
\end{tabular}




\section{References}

[1] Czajczyńska, D. et al. (2017) 'Potential of pyrolysis processes in the waste management sector', Thermal Science and Engineering Progress. Elsevier B.V., 3, pp. 171-197. doi: 10.1016/j.tsep.2017.06.003.

[2] Darmadji, P. (2002) 'DENGAN METODA REDISTILASI [ Optimation of Liquid Smoke Purification by Redistilation Method )', XIII(3).

[3] Devison (2015) Rekayasa Pirolisator Berkinerja Tinggi Untuk Peningkatan Rendemen Asap Cair. Universitas Andalas.

[4] Dirjenbun (2016) 'Statistik Perkebunan Indonesia', in Sekretariat Jenderal Perkebunan. Jakarta: Sekretaris Jenderal Perkebunan.Kementerian Pertanian.

[5] Edi Syafri dan Sri Aulia Novita (2011) 'Rekayasa Alat Pembuat Asap Cair Dengan Limbah Pertanian Sebagai Bahan Baku', in Prosiding Seminar Nasional. POLITANI Payakumbuh.

[6] Haji, A. G. (2013) 'Komponen Kimia Asap Cair Hasil Pirolisis Limbah Padat Kelapa Sawit', Jurnal Rekayasa Kimia dan Lingkungan, 9(3).

[7] Hermanto, M. and Farizy, S. (2014) 'KARET SEBAGAI KOAGULAN LATEKS', Jurnal Teknik Kimia, 20(4), pp. 14-21.

[8] Nurhayati, T., H. R. and N. B. (2005) 'Production of Mangium Wood Vinegar and Its Utilization', Jurnal of Foresty Research, 2(1), pp. 13-26.

[9] Putri, R. E., Mislaini and Ningsih, L. S. (2015) 'Pengembangan Alat Penghasil Asap Cair dari Sekam Padi Untuk Menghasilkan Insektisida Organik', Jurnal Teknologi Pertanian Andalas Andalas, 19(2), pp. 29-36.

[10] Roy, P. and Dias, G. (2017) 'Prospects for pyrolysis technologies in the bioenergy sector: A review', Renewable and Sustainable Energy Reviews. Elsevier Ltd, 77(May 2016), pp. 59-69. doi: 10.1016/j.rser.2017.03.136.

[11] Swastawati, F. (2007) 'LIQUID SMOKE PERFORMANCE OF LAMTORO WOOD AND’, Journal of Coastal Development, 10(June 2007), pp. 189-196. 